\title{
The Activation of Spores of Clostridium bifermentans
}

\author{
By P. A. GIBBS \\ The Wellcome Research Laboratories (Biological Division), Beckenham, Kent
}

(Accepted for publication 6 September 1966)

SUMMARY

The activation of spores of Clostridium bifermentans by various treatments was investigated. Mercaptoacetate did not activate the spores but inhibited the spontaneous activation which occurred in buffer alone. Sodium borohydride effected activation of spores by increasing the $\mathrm{pH}$ value above $\mathrm{pH}$ 10.0 rather than by its reducing action. The $\mathrm{pH}$ value of a suspension had a marked effect on activation; at $37^{\circ}$ spores held at less than $\mathrm{pH} 3.0$ or at $\mathrm{pH}$ 10.0 or more were activated within $1 \mathrm{hr}$. Continued incubation at an alkaline $\mathrm{pH}$ value led to a decrease in the specific requirements for germination, an effect not produced by acid $\mathrm{pH}$ values. Heat-activated spore suspensions became partially de-activated on storage unless they were continuously aerated. Spores activated at $37^{\circ}$ and $\mathrm{pH} 2.0$ or $\mathrm{pH} 7 \cdot 4$ readily became de-activated on storage, whereas spores activated at $\mathrm{pH} 10.5$ remained activated. A specific requirement of heat-activated spores for sodium ions for germination was also found.

\section{INTRODUCTION}

The transition of dormant bacterial spores to fully active vegetative forms can be divided into three distinct phases: activation, germination, outgrowth. Activation of spores or the breaking of dormancy is commonly achieved by heating spores in aqueous suspension, a process first described by Evans \& Curran (1943). It was reported, however, that reducing agents or exposure to acid $\mathrm{pH}$ values activated spores of an aerobic organism, Bacillus cereus (Keynan, Evenchik, Halvorson \& Hastings, 1964). The effect of these agents as activators of spores of anaerobic bacteria has apparently not been investigated, although it has been reported that spores of Clostridium roseum require reducing conditions for germination (Hitzman, Halvorson \& Ukita, 1957). In a previous publication (Gibbs, 1964), some of the factors which affect the germination of heat-activated spores of $C$. bifermentans were described. The present paper describes experiments on the effect of reducing agents and $\mathrm{pH}$ value as activating agents for spores of this organism and also investigations of the inorganic ion requirement for germination.

\section{METHODS}

The technique for the production of suspensions of spores of Clostridium bifermentans (CN 1617, Wellcome Research Laboratories' Culture Collection), activation by heat and estimation of germination were as previously described (Gibbs, 1964). A decrease in extinction of 55-60\% was found to correlate closely with phase-darkening of $95-100 \%$ of the spores and, for speed and convenience, the decrease in extinction was used as a measure of germination. Since spores which were not activated did not 
germinate within $1 \mathrm{hr}$ at $37^{\circ}$ on the addition of germinants, the degree of germination (\% decrease in extinction) was taken as a direct measure of the degree of activation. All work with spore suspensions was done in $0.1 \mathrm{M}-[\mathrm{Na} / \mathrm{K}]$ phosphate buffer $(\mathrm{pH} 7 \cdot 4)$ unless otherwise stated.

Treatment of spores with reducing agents. For studies on the effect of mercaptoacetic acid on spores, the free acid was titrated to $\mathrm{pH} 7.4$ with $10 \mathrm{~N}-\mathrm{NaOH}$, and added to spores suspended in phosphate buffer. Sodium borohydride and lithium aluminium hydride (L. Light and Co., Colnbrook, England) were added as solids $(0.5-1.0 \mathrm{mg} . / \mathrm{ml}$.) to spores suspended in phosphate buffer (0.D. $680 \mathrm{~m} \mu, c a .1 \cdot 5$; Hilger 810 Biochem. Absorptiometer, $15 \mathrm{~mm}$. diam. tube). Treated spores were washed twice with phosphate buffer before testing for germination.

Treatment of spores with acid or alkali. Spores were suspended in phosphate buffer, titrated to the required $\mathrm{pH}$ value with $\mathrm{NaOH}$ or $\mathrm{HCl}$, and incubated at $37^{\circ}$. Samples were removed and the spores washed twice with phosphate buffer and tested for germination.

De-activation of spores. After activation by heating or exposure to acid or alkali, spores were washed with phosphate buffer and stored as suspensions in this buffer at $4^{\circ}$ and at room temperature $\left(16-20^{\circ}\right)$ in screw-capped bottles three-quarters full, tightly screwed down to minimize aeration. A heat-activation spore suspension was also stored at room temperature with a current of sterile air bubbled through it. Two samples were removed at intervals from the stored suspensions, one was heatshocked (at $85^{\circ}$ for $10 \mathrm{~min}$.) and both were tested for germination.

Extraction of phosphate buffer with diphenyl thiosemicarbazone (dithizone). Phosphate buffer $(200 \mathrm{ml}$.) was extracted ten times with $10 \mathrm{ml}$. portions of dithizone dissolved in chloroform $(5 \mathrm{mg}$. $100 \mathrm{ml}$.) Dithizone remaining in the buffer was extracted with chloroform and excess chloroform removed by warming and aerating.

\section{RESULTS}

\section{Effect of reducing agents on spores of Clostridium bifermentans}

Incubation of spores of Clostridium bifermentans at $16-20^{\circ}$ in the presence of 0.01$0.5 \%$ mercaptoacetate for 2-3 days did not activate the spores to any greater degree than did incubation in buffer alone. However, after incubation for 7 days spores suspended in buffer alone had become markedly activated, whereas in the presence of mercaptoacetate little or no activation had occurred (Fig. 1 A, B). At all times heating was fully effective in activating the washed spores (Fig. 1, $A^{\prime}, B^{\prime}$ ).

Incubation of spores for $6 \mathrm{hr}$ at $16-20^{\circ}$ in the presence of the reducing agent sodium borohydride achieved full activation of the spores, but lithium aluminium hydride was without effect. However, it was found that the addition of sodium borohydride caused an increase of $\mathrm{pH}$ value to 9-10.5, depending on the amount added. It seemed possible, in the light of the results of Keynan et al. (1964), that either the $\mathrm{pH}$ value attained or the reducing conditions were reponsible for the activation observed. The effect of $\mathrm{pH}$ value was therefore investigated.

\section{Effect of $p H$ value of the suspension on the activation of spores}

Since it appeared possible that alkaline $\mathrm{pH}$ values could activate spores of Clostridium bifermentans and it had been reported that acid $\mathrm{pH}$ values activated spores of 
Bacillus cereus (Keynan et al. 1964), the effect of a range of $\mathrm{pH}$ values was examined; the results are summarized in Fig. 2. Marked activation occurred at $\mathrm{pH} 10 \cdot 0$ and above, an effect not noted by Keynan et al. (1964), and also at $\mathrm{pH} 2.0$; but in the range $\mathrm{pH} 3 \cdot 0-9 \cdot 0$ the activation was much less marked. It was shown that the high concentrations of $\mathrm{Na}^{+}$or $\mathrm{Cl}^{-}$ions, added when adjusting the $\mathrm{pH}$ values, were not responsible for the activation observed. It appeared therefore that the activating effect of $\mathrm{NaBH}_{4}$ could be entirely accounted for by the alkaline $\mathrm{pH}$ value attained on addition of this compound.

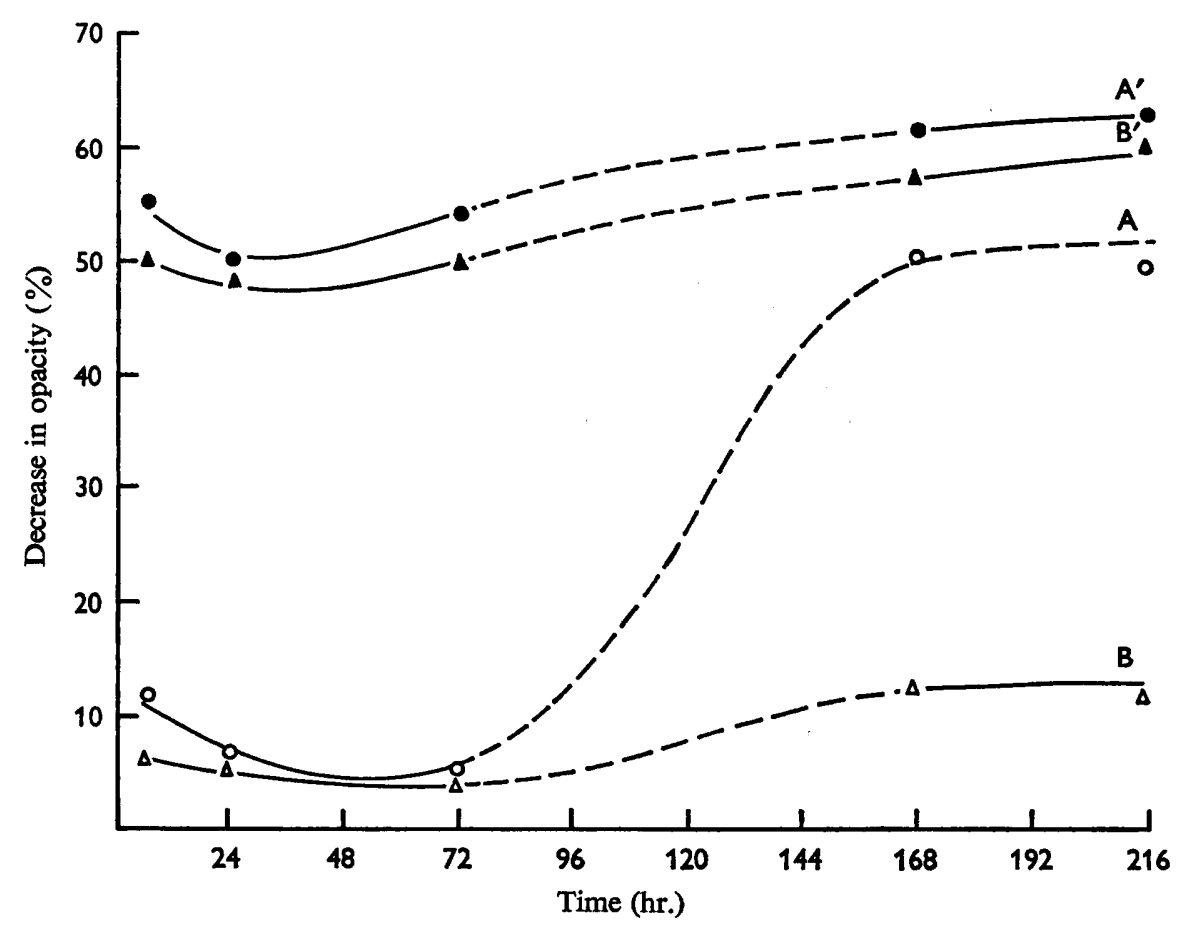

Fig. 1. Effect of mercaptoacetate on spores of Clostridium bifermentans during storage at 16-20. Spores were washed twice before testing for germination. $A$, spores suspended in $0.1 \mathrm{M}$-phosphate (pH 7.4); $\mathrm{B}$, spores suspended in $0.1 \mathrm{M}$-phosphate $(\mathrm{pH} 7.4)+0.01 \%$ mercaptoacetate; $A^{\prime}$ and $B^{\prime}$, as $A$ and $B$ but the spores were heat shocked ( $85^{\circ}$ for $10 \mathrm{~min}$.) before testing for germination.

Samples removed at intervals from a spore suspension incubated at $\mathrm{pH} 10.5$ and $37^{\circ}$ showed an increasing degree of activation during incubation, rising to complete activation after $30 \mathrm{~min}$; the rate of activation appeared to be almost linear up to 20 min. (Fig. 3). Little activation occurred in spore suspensions incubated at $\mathrm{pH} 7 \cdot 4$ and $37^{\circ}$ for periods of up to $1 \mathrm{hr}$., although continued incubation of these spores led to $60-70 \%$ activation in $2 \mathrm{hr}$.

\section{Annulment of activation ('de-activation') on storage}

Although activated spores of aerobic bacteria have been reported to undergo de-activation on storage (Curran \& Evans, 1947; Desrosier \& Heiligman, 1956; Keynan et al. 1964), there appear to be no reports of the phenomenon in activated 
spores of anaerobic bacteria. It was therefore decided to investigate whether spores of Clostridium bifermentans previously activated by the treatments outlined above, would undergo de-activation on storage.

Spores which were activated by incubation at $37^{\circ}$ and $\mathrm{pH} 7 \cdot 4$ for $2 \mathrm{hr}$. when stored at $16-20^{\circ}$ or at $4^{\circ}$ in tightly capped bottles (conditions of minimal aeration) became fully de-activated in 6-7 days. Heating at $85^{\circ}$ for $10 \mathrm{~min}$. fully re-activated these spore suspensions at all times during storage.

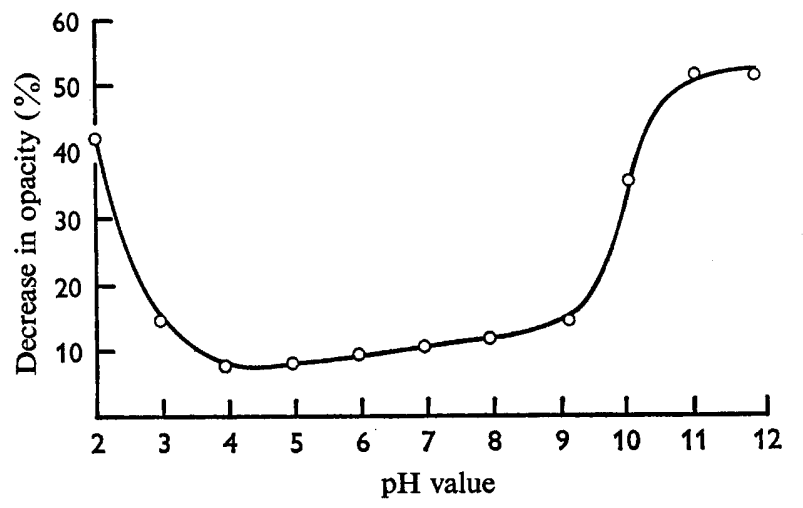

Fig. 2

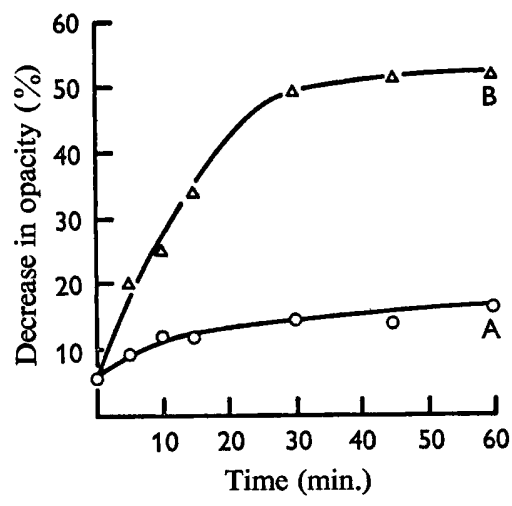

Fig. 3

Fig. 2. Activation of spores of Clostridium bifermentans by treatment at various $\mathrm{pH}$ values. Spores were suspended in $0 \cdot 1 \mathrm{M}$-phosphate titrated to various $\mathrm{pH}$ values with $\mathrm{NaOH}$ or $\mathrm{HCl}$, incubated for $2 \mathrm{hr}$. at $37^{\circ}$, washed twice with $0.1 \mathrm{M}$-phosphate $(\mathrm{pH} \mathrm{7.4)}$ and tested for germination.

Fig. 3. Activation of spores of Clostridium bifermentans at $\mathrm{pH} 10 \cdot 5,37^{\circ}$. A, spores suspended

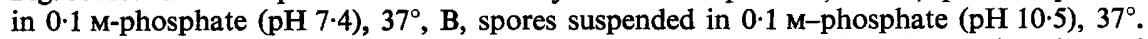
Samples were removed at intervals, washed twice with $0 \cdot 1 \mathrm{M}$-phosphate (pH 7.4) and tested for germination.

Spores heat-activated at $\mathrm{pH} 7 \cdot 4$ and stored under the same conditions, showed a rather slower rate of de-activation, a loss of $50 \%$ of activation being observed over a period of 10-14 days. Re-activation of these spores by heating at $85^{\circ}$ for $10 \mathrm{~min}$. did not occur. When heat-activated spores were stored with continuous aeration at

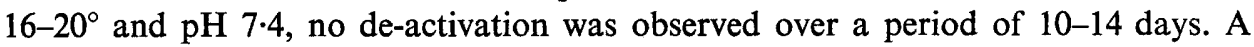
second heat treatment of these spores immediately before the addition of germinants, led to a much smaller degree of germination.

Spores activated at $\mathrm{pH} 2.0$ showed a steady decrease in the degree of activation up to 10 days of storage, when approximately $30 \%$ of spores remained in the activated state. Heating of samples of these spore suspensions $\left(85^{\circ}\right.$ for $10 \mathrm{~min}$.) during the first $48 \mathrm{hr}$ of storage showed a decrease in the degree of germination, but later heated samples showed an increased degree of germination on the addition of germinants as compared with unheated samples. It is possible that spores activated at $\mathrm{pH} 2.0$ become sensitive to heat, but on de-activation regain their heat resistance, and also show a requirement for re-activation. 


\section{Germination of spores of Clostridium bifermentans: the minimum requirements}

In a previous paper (Gibbs, 1964) it was reported that lactate, L-phenylalanine and $\mathrm{L}$ - $\alpha$-alanine were all essential for the germination of heat-activated spores of Clostridium bifermentans suspended in phosphate buffer. During the present work it was found that germination of heat-activated spores occurred only when all three compounds were present simultaneously; addition and removal of these three compounds in all possible sequences did not lead to germination of spores. When similar experiments were made with spores activated at $\mathrm{pH} 10.5$ and $37^{\circ}$, rapid and complete germination of the washed spores occurred in the presence of $\mathrm{L}-\alpha$-alanine +lactate or $\mathrm{L}-\alpha$-alanine $+\mathrm{L}$-phenylalanine when the activation time was $2 \mathrm{hr}$ or longer. All three compounds were required however for the germination of spores activated at $\mathrm{pH} 3.0$ and $37^{\circ}$ for $2 \mathrm{hr}$. Spores activated at $\mathrm{pH} 10.5$ for $2 \mathrm{hr}$ at $37^{\circ}$ were therefore able to dispense with either $L$-phenylalanine or lactate, in the presence of $L-\alpha$-alanine, for germination. The rates at which spores lost the requirement for lactate or L-phenylalanine during activation at $\mathrm{pH} 10.8$ and $37^{\circ}$ are shown in Table 1 . It is seen that the requirement for L-phenylalanine was lost steadily during the activation period, but the requirement for lactate was not lost until after at least $60 \mathrm{~min}$. exposure to $\mathrm{pH} 10.8$ at $37^{\circ}$. The presence of $\mathrm{L}-\alpha$-alanine was essential for germination at all times.

\section{Table 1. Variations in the minimum requirements for germination}

Spore suspensions were incubated at $37^{\circ}$ at $\mathrm{pH} 7 \cdot 4$ or $\mathrm{pH} 10 \cdot 8$. Samples were removed at intervals, the spores washed with phosphate buffer $(\mathrm{pH} \mathrm{7.4)}$ and tested for germination with $\mathrm{L}-\alpha$-alanine + lactate and with $\mathrm{L}-\alpha$-alanine $+\mathrm{L}$-phenylalanine. Extinction values $680 \mathrm{~m} \mu$ were measured over $60 \mathrm{~min}$. and the decrease in extinction over $60 \mathrm{~min}$. calculated (\%), $\left(\frac{\left(E_{0}-E_{60}\right.}{E_{0}} \times 100\right)$.

Activation time at $37^{\circ}$ (min.)

0
5
10
15
30
45
60
120

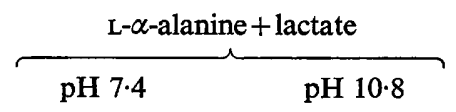

Decrease in extinction $\left(E_{680}\right)$ over $60 \mathrm{~min} .(\%)$

$\overbrace{\text { pH } 7.4}^{\text {L- } \alpha \text {-alanine }+ \text { L-phenylalanine }}$

$\begin{array}{lr}5 & 0 \\ 0 & 0 \\ 0 & 0 \\ 2 \cdot 0 & 0 \\ 3 \cdot 2 & 0 \\ 3 \cdot 0 & 0 \\ 0 & 5 \\ 0 & 35\end{array}$

Inorganic ions required for germination. To investigate the requirements for inorganic ions for germination, spores were centrifuged from phosphate buffer suspension, washed five times with distilled water or with tris- $\mathrm{HCl}$ buffer, and resuspended in distilled water or tris- $\mathrm{HCl}$. The suspensions were heat-activated $\left(85^{\circ}\right.$ for $10 \mathrm{~min}$.) and $\mathrm{L}-\alpha-$ alanine, L-phenylalanine and lactate added. Germination of these suspensions was not observed during a period of $2 \mathrm{hr}$. When $0.1 \mathrm{M}$-phosphate buffer was added to these suspensions after $2 \mathrm{hr}$ incubation, rapid and complete germination occurred. Further work showed that the degree of germination was proportional to the concentration of phosphate buffer, rising to a maximum at approximately $0.1 \mathrm{M}$. Heat treatment there- 
fore was effective in producing activation of spores in distilled water or in tris- $\mathrm{HCl}$ buffer, but some component of the phosphate buffer appeared to be essential for the germination process. Trace metals have been shown to be active in promoting germination (Levinson \& Sevag, 1953; Levinson \& Hyatt, 1955). For this reason routine phosphate buffer was extracted with a solution of dithizone in chloroform. Spores suspended in dithizone-extracted buffer at first showed a decrease in the degree of germination, but this was traced to residual traces of chloroform in the buffer and when this effect was eliminated, the extracted buffer was found to be as effective as was non-extracted buffer in producing rapid and complete germination. The effect therefore appeared not to reside in the trace elements removed by dithizone but in the major ions present. The routine buffer was prepared from $\mathrm{KH}_{2} \mathrm{PO}_{4}$ titrated to $\mathrm{pH} 7 \cdot 4$ with $\mathrm{NaOH}$. Heat-activated spores suspended in a buffer made by substituting $\mathrm{KOH}$ for $\mathrm{NaOH}$ did not germinate on addition of $\mathrm{L}-\alpha$-alanine $+\mathrm{L}$-phenylalanine + lactate. From this it appeared that it was the sodium ions in the original buffer that were essential for germination. To test this, tris- $\mathrm{HCl}$ buffer was prepared in $0 \cdot 1 \mathrm{M}-\mathrm{NaCl}$. Heatactivated spores suspended in this buffer showed complete and rapid germination on the addition of the three specific germinants. However, when $\mathrm{NaCl}$ was replaced by $\mathrm{KCl}$, germination did not occur. It would therefore seem that heat-activated spores of Clostridium bifermentans have an obligate requirement for sodium ions for germination.

\section{DISCUSSION}

It has long been known that many bacterial spores require some form of treatment before rapid germination in a nutrient medium will occur. This treatment has usually consisted of a short period of heating, so-called heat-shock, which was first described by Evans \& Curran (1943) and has since been well-documented (Murrell, 1961). The term in use at present for this process is 'activation', describing an increase in metabolic activity of activated spores (Church \& Halvorson, 1957) and also increased sensitivity to inimical reagents and heat (Halvorson \& Church, 1957). Vinter (1960, 1961) showed that much of the inert nature of bacterial spores may be attributed to the presence of large numbers of cystine disulphide bonds present in the spore-coat protein, and that these are broken during germination. It was possible that reduction of these bonds would cause a modification of the structure of the spore-coat protein, thus activating spores either by increasing the permeability of the spore-coat to germination agents, or by exposure of the enzymes necessary for germination, or by a combination of these effects. The results obtained here with spores of Clostridium bifermentans treated with mercaptoacetate indicated that no activation occurred and indeed a marked inhibition of activation was observed. Such was not apparently the case with spores of Bacillus cereus since mercaptoacetate effected activation (Keynan et al. 1964). However, mercaptoacetate is not without some effect on spores of C. bifermentans, since it has been reported that spores so treated are lysed by hydrogen peroxide or lysozyme (Gould \& Hitchins, 1963).

From our experiments on activation during incubation at various $\mathrm{pH}$ values, it would appear that activation occurs over a wide range of $\mathrm{pH}$ values, but that the rate of activation is greater at the extremes of the range. If activation is due to a reversible denaturation-like process of the spore-coat protein, as suggested by Keynan et al. (1964), then it is to be expected that the rate of activation would increase as extremes 
of $\mathrm{pH}$ value or temperature are approached. However, it appears that activation of the spores of Clostridium bifermentans at $\mathrm{pH} 10.5$ is more radical than activation at neutral or acid $\mathrm{pH}$ values or by heat-shock, since the germination requirements are then simplified and also de-activation does not occur on storage.

De-activation of heat-activated spores of Clostridium bifermentans has been shown to occur most readily in conditions of partial anaerobiosis and not in highly aerated conditions. This suggests that enzymic reactions are necessary for de-activation and not oxidation of sulphydryl groups since the organism is a strict anaerobe.

Many workers have noted a requirement for inorganic ions for spore germination (e.g. Levinson \& Sevag, 1953; Rode \& Foster, 1962 a, $b$; Fleming \& Ordal, 1964) but most of these results have been obtained with spores of species of the genus Bacillus. There has apparently been no other report of an obligate requirement for $\mathrm{Na}^{+}$ions for the germination of spores of an obligate anaerobe like Clostridium bifermentans.

The author wishes to thank Miss B. M. Hill and Mr R. J. Paye for their valuable technical assistance.

\section{REFERENCES}

Church, B. D. \& Halvorson, H. O. (1957). Intermediate metabolism of aerobic spores. 1. Activation of glucose oxidation in spores of Bacillus cereus var. terminalis. J. Bact. 73, 470.

Curran, H. R. \& Evans, F. R. (1947). The viability of heat-activatable spores in nutrient and non-

- nutrient substrates as influenced by prestorage or poststorage heating and other factors. J. Bact. 53, 103.

Desrosier, N. W. \& Heiligman, F. (1956). Heat-activation of bacterial spores. Food Res. $21,54$.

Evans, F. R. \& CURRAN, H. R. (1943). The accelerating effect of sublethal heat on spore germination in mesophilic aerobic bacteria. J. Bact. 46, 513 .

Fleming, H. P. \& ORDAL, Z. J. (1964). Response of Bacillus subtilis spores to ionic environments during sporulation and germination. J. Bact. 88, 1529.

GIBBS, P. A. (1964). Factors affecting the germination of spores of Clostridium bifermentans. J. gen. Microbiol. 37, 41.

Gould, G. W. \& Hrtchins, A. D. (1963). Sensitization of bacterial spores to lysozyme and to $\mathrm{H}_{2} \mathrm{O}_{2}$ with agents which rupture disulphide bonds. J. gen. Microbiol. 33, 413.

Halvorson, H. O. \& ChuRCH, B. D. (1957). Biochemistry of spores of aerobic bacilli with special reference to germination. Bact. Rev. 21, 112.

Hitzman, D. O., Halvorson, H. O. \& Ukita, T. (1957). Requirements for production and germination of spores of anaerobic bacteria. J. Bact. 74, 1.

Keynan, A., Evenchik, Z., Halvorson, H. O. \& Hastings, J. W. (1964). Studies on the activation of bacterial endospores. J. Bact. 88, 313.

Levinson, H. S. \& HyatT, M. T. (1955). Stimulation of germination and respiration of Bacillus megaterium spores by manganese, L-alanine and heat. J. Bact. 70, 368 .

LeVinson, H. S. \& SevaG, M. G. (1953). Stimulation of germination and respiration of the spores of Bacillus megaterium by manganese and monovalent anions. J. gen. Physiol. 36, 617.

MURRELL, W. G. (1961). Spore formation and germination as a microbial reaction to the environment. Symp. Soc. gen. Microbiol. 11, 100.

RODE, L. J. \& FOSTER, J. W. (1962a). Ionic germination of spores of Bacillus megaterium QM B 1551. Arch. Microbiol. 43, 183.

RoDE, L. J. \& Foster, J. W. (1962b). Ionic and non-ionic compounds in the germination of spores of Bacillus megaterium Texas. Arch. Mikrobiol. 43, 201.

VINTER, V. (1960). Spores of microorganisms. VIII. The synthesis of specific Ca-and cystinecontaining structures in sporulating cells of bacilli. Folia Microbiol. 5, 217.

VINTER, V. (1961). The formation of cystine-rich structure in sporulating cells and its possible role in the resistance of spores. In Spores 2. Ed. by H. O. Halvorson. Minneapolis 15, Minn.: Burgess Publishing Co. 
